\title{
Determinants of Street Entrepreneurial Success
}

\author{
Ajay Thapa \\ Archana Thulaseedharan \\ Arup Goswami \\ Lucky Prasad Joshi
}

\begin{abstract}
Street entrepreneurship is one of the rapidly growing areas in the present business world. Understanding the factors affecting this business is important for the business people. This study has revealed many facts concerning the socio-economic and motivational factors affecting street entrepreneurship. Among many socio-economic and motivational factors, size of initial investment, number of workers, family business and promising demand of product/services are some of the major determinants of street entrepreneurial success.
\end{abstract}

Keywords : Street entrepreneurship, entrepreneurial success

Entrepreneurship is one of the emerging areas of business. It ranges from a solo project/business to major undertakings creating many job opportunities. It also may range from a few thousand rupees investment to a big chunk of investment. No matter the size of the investment and the number of individuals investing in a business, basically the entrepreneurs are the individuals or a group of individuals who posses a new enterprise or business or a venture and assume the full accountability for the inherent risks and the outcomes.

There can be various factors like socio-economic, and motivational factors that affect the entrepreneurship and entrepreneurial success. If we look at the literature of entrepreneurial success across the world, we can find various factors affecting entrepreneurial success. For example, Lee and Denslow (2005) in their study have found that lack of capital and lack of experience is one of the major factors affecting entrepreneurial success. Similarly education is another factor that influences entrepreneurial success. Thapa (2007) in his study in Nepal has found that the education has positive effect on entrepreneurial success. Likewise Indarti and Langenverg in their study in Indonesia also have stated that education of the entrepreneurs was found to have significant relationship with business success. Similarly Cooper (1985) has stated that the factors like experience/occupational background of the entrepreneurs, family members, skill, knowledge, role models, supports and the economic 
conditions of the entrepreneurs, access to capital, etc. are some of the motives that lead to entrepreneurial success. In another study by T.K.Panda also says that previous experiences lead to the success of the entrepreneurs. Likewise, Hisrich (1990) and Krueger (1993) also states that the human capital elements of the entrepreneurs such as education, age, work history, role model and support networks have positive contributions in business (quoted in Rose et. al., 2006).

Similarly, Lussiers and Pfeifer (2001) also summarized that the entrepreneurs with higher education level and experiences have greater chances of succeeding than the people without education and experiences (quoted in Rose et. al., 2006). Likewise, Mehralizadeh, Y and Sajady, S.H. (2006) have also stated that the success of the business depends on the socioeconomic factors such as education, skills, and training. In the same way, Rose et. al. (2006) themselves have also found that skill, education and experiences and financial support are some of the major factors affecting for success in business. CIBC World Markets Inc. (2004) states that high level of education, role model, ownership of the business are some of the major factors to growth revenue in the small business. However, Minniti and Bygrave (2003) have stated that people with more education are not necessarily more entrepreneurial. Raman (2004) in his study in Kerala has found that motivational factors such as initiatives, third party assistance, encouragement by family and friends, skill and experiences, independentness leads to the success of the entrepreneurs. Swinney and Runyan (2007) state that generating income and creating job for themselves, support from family and friends are the leading factors for motivating the people to become successful entrepreneurs.

Vastrapur is one of the places in Ahmedabad where different forms of entrepreneurships are found. Street entrepreneurship is one among the different forms of entrepreneurship. Again among different form of street entrepreneurship in Vastrapur, everyday fast food business in the street from evening to late to the midnight is a typical type. As discussed above on different factors affecting success of enterprises/businesses across the world, here in Vastrapur also there might be different factors like socio-economic and motivational, which determine the success of their business. Thus, this study has tried to find out the factors that ascertain the entrepreneurial success with the help of the following research questions:

\section{Key Variables}

Entrepreneurship: Entrepreneurship is the recognition and pursuit of opportunity without regard to the resources you currently control, with confidence that you can succeed, with the flexibility to change course as necessary, and with the will to rebound from setbacks. It is also known as the art of finding profitable solutions to problems. Entrepreneurship in this study is the street entrepreneurship. 
Street Entrepreneurs: Street Entrepreneurs are the persons who initiate, take risks, organize, manage and control the affairs of business units in order to supply good and services. They find ways to acquire the resources they need to achieve their goals. Street Entrepreneurs in this study are the people doing street fast food business in Vastrapur, Ahmedabad, India.

Entrepreneurial success: Generally the growth in income or profit made by providing good and services is known as a measure of success of entrepreneurs. In this study entrepreneurial success has been measured based on the basis of profit from the business.

\section{Data and Methodology}

This study has been carried out based on the primary data. The data were collected using a direct personal interview with the street entrepreneurs in Vastrapur, Ahmedabad, India. The data have been analyzed using hierarchical multiple regression method in SPSS software. The basic assumptions of the regression such as auto-correlation of residuals, multi-collinearity, normality of regression standardized residuals, linearity of regression standardized residuals, and homoscadasticity have been tested. After satisfying all above stated assumptions of regression, the data were analyzed using bivariate correlation and hierarchical multiple regressions. The study has tested the following hypotheses to draw the conclusions:

\subsection{Hypotheses}

$\mathrm{H}_{1}$ : Level of education has positive relationship with the profit from the street business.

$\mathrm{H}_{2}$ : There is positive relationship between level of different motivational factors and the profit from business.

$\mathrm{H}_{3}$ : The years of schooling has positive effect on profit from the business.

$\mathrm{H}_{4}$ : The number of workers has significant positive effect on profit from the business.

$\mathrm{H}_{5}$ : The size of initial investment in the business has significant positive effect on the profit from the business.

$\mathrm{H}_{6}$ : Motivational factors are likely to affect the profit from the business.

\subsection{Models of the Study}

$$
\hat{Y}=\hat{\beta}_{0}+\hat{\beta}_{\text {YOS }} X_{\text {iYOS }}+\hat{\beta}_{\text {IIB }} X_{\text {illB }}+\hat{\beta}_{\text {NOW }} X_{\text {inOW }}+\hat{\varepsilon}_{i}
$$

\section{Model I: Socio-economic factors}

The first model of the study includes the socio-economic variables where $\hat{Y}$ represents profit from the business and $X_{\text {iYos }}$ represents the predictor variable Years of schooling of the entrepreneur, $X_{\text {illB }}$ represents the Initial investment in business and $X_{\text {inow }}$ represents the Number of workers in the business. The coefficients of $X_{\text {iYOS }}, X_{\text {іІів }}$ and 
$X_{\text {inow }}$ explain the effect of each year increase in the years of schooling, each rupee increase in initial investment and each worker increase in the business respectively on the profit from the business $(\hat{Y}) \cdot \hat{\varepsilon}_{\mathrm{i}}$ represents the random error that is the influence of other factors on the profit from business $(\hat{\mathrm{Y}})$.

Model II: Motivational factors

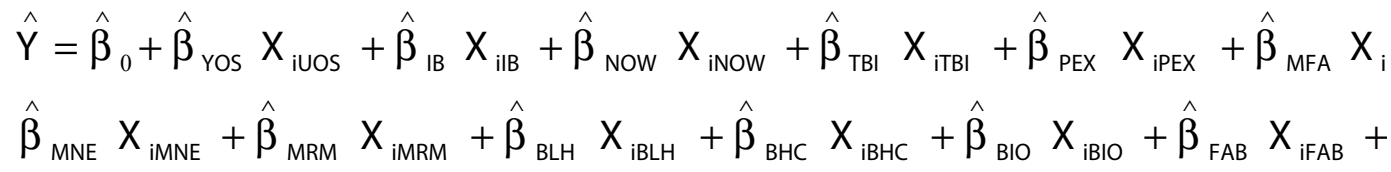

In this model, in addition to the socio- economic factors in model I, motivational factors are inserted to see their effect on the profit from street business. The factors in the model $X_{\text {itBI }}, X_{\text {iPEX }}, X_{\text {iMFA }}, X_{\text {iMFR }}, X_{\text {iMNE }}, X_{\text {iMRM }}, X_{\text {iBLH }}, X_{\text {iBHC }}, X_{\text {iBIO }}, X_{\text {iFAB }}$, and $X_{\text {iPRD }}$ represent the motivation to become independent, previous experience, motivation from family, friends, neighbor, role model, business for livelihood, household capital, better income opportunity, family business and Promising demand of the product/services respectively and the coefficient of these factors explain the effect of these motivational factors on the profit from business $(\hat{\mathrm{Y}})$.

\section{Results and Discussion}

\subsection{Do socio-economic factors have any relation with profit from business?}

Among many socio-economic factors, education, investment in business and worker size seems to have significant relation with profit. The study has identified that there are sufficient evidences to claim the moderate positive relationship $(r=0.506, p<0.01$, Table 1) between education level and profit from the business. Similarly, the amounts of initial investment in the business and number of workers in the business have also moderate positive relationship with profit $(\mathrm{r}=0.420, \mathrm{p}<0.05$ and $\mathrm{r}=0.520, \mathrm{p}<0.01$ respectively, Table 1). The following table illustrates the details of the correlation of socio-economic factors with profit in the business.

Table 1: Socio-economic factors and their relation with profit from business

\begin{tabular}{|l|r|}
\hline \multicolumn{1}{|c|}{ Socio-economic factors } & Average profit \\
\hline Years of schooling & $0.506^{* *}$ \\
\hline Initial investment in business & $0.420^{*}$ \\
\hline Number of Workers & $0.520^{* *}$ \\
\hline
\end{tabular}

*Correlation is significant at the 0.05 level

**Correlation is significant at the 0.01 level 


\subsection{Do motivational factors have any relation with profit from business?}

Among many motivational factors, only few motivational factors have sufficient evidences to claim the relation with profit in the business. The study has found that level of motivation to become independent and promising demand of the product/services in starting business has positive relationship with profit $(r=0.316, p<0.10$ and $r=0.331, p<0.10$, Table 2. However, in case of other motivational factors, sufficient evidences could not be found to explain the relationship with profit. Table 2 depicts a detail picture of correlation between motivational factors and profit in business.

Table 2: Motivational factors and their relation with profit from business

\begin{tabular}{|l|r|}
\hline \multicolumn{1}{|c|}{ Motivational factors } & Average profit \\
\hline To become independent & $0.316^{+}$ \\
\hline Previous Experience & 0.055 \\
\hline Training/Skills & 0.013 \\
\hline Motivation from family & -0.005 \\
\hline Motivation from friends & 0.011 \\
\hline Motivation from neighbors & -0.271 \\
\hline Motivation from role model & -0.123 \\
\hline Business for livelihood & 0.096 \\
\hline Business for household capital & -0.073 \\
\hline Business for better income opportunity & -0.053 \\
\hline Family Business & 0.160 \\
\hline Promising demand of the product/services & $0.331^{+}$ \\
\hline${ }^{+}$Correlation is significant at the 0.10 level & \\
\hline
\end{tabular}

\subsection{Regression Analysis}

The hierarchical multiple regression was run to analyze the effect of the socioeconomic and motivational factors on profit from the business. Among many factors, some factors such as number of workers, initial investment in the business, motivated due to promising demand of the product of services to start business are found to have significant effect on profit. Basically the final model of the study which includes all above stated four factors, can explain around 51 percent of variance in the profit $(p<0.05$, Table 3$)$.

\subsubsection{What are the socio-economic and motivational factors affecting entrepreneurial success?}

In the first model, some socio-economic variables such as years of schooling, initial investment in the business, and number of workers were included. First model shows the significant effect of all socio-economic factors inserted in the model. However after introducing some motivational factors, the effect of level of education or years of schooling 
of the entrepreneurs has demolished. Based on the model II or final model of the study, it can be analyzed that the size of initial investment in the business has also significant positive effect on profit. Regression analysis shows that every additional rupee increase in investment returns rupee 0.059 per month $(\mathrm{p}<0.10$, Table 3$)$. Similarly, the number of workers has positive effect on profit. If number of workers increases by one unit, the additional worker will give the return of rupees 707.167 per month $(p<0.10$, Table 3$)$. Likewise, among the motivational factors, only one factor i.e. promising demand of the product/services has the significant effect on profit from business $(\beta=0.488, \mathrm{p}<0.05)$. Table 3 illustrates a more detail picture of the multiple regression analysis.

Table 3: Hierarchical Multiple Regression Analysis ${ }^{\mathrm{a}}$

\begin{tabular}{|c|c|c|c|c|c|c|}
\hline \multirow{3}{*}{ Predictor variables } & \multicolumn{3}{|c|}{ Model I } & \multicolumn{3}{|c|}{ Model II } \\
\hline & \multicolumn{2}{|c|}{$\begin{array}{l}\text { Unstandardized } \\
\text { Coefficients }\end{array}$} & \multirow{2}{*}{$\begin{array}{c}\text { Standardized } \\
\text { Coefficients } \\
\text { Beta } \\
\end{array}$} & \multicolumn{2}{|c|}{$\begin{array}{c}\text { Unstandardized } \\
\text { Coefficients } \\
\end{array}$} & \multirow{2}{*}{$\begin{array}{c}\text { Standardized } \\
\text { Coefficients } \\
\text { Beta }\end{array}$} \\
\hline & $\mathrm{B}$ & Std. Error & & $\mathrm{B}$ & Std. Error & \\
\hline (Constant) & 187.146 & 1585.109 & & -746.430 & 3075.883 & \\
\hline Years of schooling & $446.295 *$ & 169.038 & 0.390 & 251.165 & 238.723 & 0.220 \\
\hline Initial investment in business & $0.072 *$ & 0.026 & 0.381 & $0.059^{+}$ & 0.030 & 0.313 \\
\hline Number of workers & $747.132 *$ & 329.027 & 0.338 & $707.167^{+}$ & 400.322 & 0.320 \\
\hline To become independent & & & & 384.783 & 330.933 & 0.215 \\
\hline Previous Experience & & & & 160.082 & 256.971 & 0.096 \\
\hline Motivation from family & & & & -22.115 & 201.731 & -0.018 \\
\hline Motivation from friends & & & & 28.114 & 240.124 & 0.019 \\
\hline Motivation from neighbors & & & & 106.552 & 413.824 & 0.056 \\
\hline Motivation from role model & & & & -430.849 & 306.576 & -0.300 \\
\hline Business for livelihood & & & & -133.722 & 281.210 & -0.076 \\
\hline Business for household capital & & & & -542.117 & 264.905 & -0.411 \\
\hline Business for better income opportunity & & & & -36.786 & 275.761 & -0.028 \\
\hline Family Business & & & & 447.801 & 259.191 & 0.343 \\
\hline $\begin{array}{l}\text { Promising demand of the product/ } \\
\text { services }\end{array}$ & & & & 685.051 & 239.741 & $0.488^{*}$ \\
\hline Adjusted R2 & & $0.467 * * *$ & & & $0.506 * *$ & \\
\hline
\end{tabular}

a Dependent Variable: Monthly average profit

*** Significant at $<0.001 ; * *$ Significant at $<0.01 ; *$ Significant at $<0.05 ;{ }^{+}$Significant at $<0.1$; Durbin-Watson statistics: 2.129

\subsubsection{Test of Hypotheses}

In the inferential analysis has forecasted the following results in hypotheses testing:

1. The first hypothesis $\mathrm{H}_{1}$ :"Level of education has positive relationship with entrepreneurial success" is accepted since it is fond that the years of schooling has moderate positive relationship with profit from the business $(\mathrm{r}=0.506, \mathrm{p}<0.01)$.

2. The second hypothesis $\mathrm{H}_{2}$ : "There is positive relationship between level of different motivational factors and the profit from business" is partly accepted since among ten motivational factors included in the model, only two of them: to become independent and 
promising demand of the product/services are accepted $(r=0.316, p<0.10$ and $r=0.331$, $\mathrm{p}<0.10$ respectively).

3. The third hypothesis $\mathrm{H}_{3}$ : "The years of schooling has positive effect on profit from business" is rejected $(\mathrm{p}>0.10)$.

4. The fourth hypothesis $\mathrm{H}_{4}$ : The number of workers has significant positive effect on profit from the business" is accepted since it is observed that every additional worker in the business contributes rupees 707.167 on profit $(p<0.10)$.

5. The fifth hypothesis $\mathrm{H}_{5}$ : "The size of initial investment in the business has significant positive effect on the profit from the business" is accepted since it is found that every additional rupee investment in the business returns the 0.059 rupee on profit $(\mathrm{p}<0.10)$.

6. The sixth hypothesis $\mathrm{H}_{6}$ : "Motivational factors are likely to affect the profit from the business", only one hypothesis such as motivation due to promising demand of the product/services is accepted $(\beta=0.488, \mathrm{p}<0.05)$.

\section{Results Discussion}

Naturally the entrepreneurs after starting some businesses are supposed to earn profit out of those businesses. Street entrepreneurs are also not exception. If we have a glance to the literature, we find several socio-economic and motivational factors affecting income or profit in businesses. This study which has been carried out based on the primary data collected from the entrepreneurs doing business on the street of Vastraur, Ahmedabad, India, also has found out some socio-economic and motivational factors having significant effects and some not having significant effects on the profit from the street business. For example, although the majority of the literatures tell that education has positive effect on the earning from business, here in this study, even though it has significant positive correlation with profit from business and also has a positive regression coefficient, due to the lack of sufficient evidences, this hypothesis is not accepted. It might be because the street business is a small business for which simple calculation to keep income, expenditure and profit is enough. In this kind of business, primary level education also can be sufficient enough. Hence higher education level might not have any such significant difference on profit.

As usual in the literatures, this study also has found that number of workers have significant positive effect on the profit from street business. Obviously, in every business, up to a point of optimal level of return, every additional worker is expected to contribute some more extra benefit or profit otherwise as the basic philosophy of the business there is not point in adding extra workers.

The study has also found that the size of the investment in the business has also positive effect on profit. It is obvious that like number of workers, until the investment in the 
business reaches to the point of optimal level of return, every additional rupee investment in the business is also expected to contribute an extra rupee on the income or profit.

Among many motivational factors as found in the literature to have effect on income or profit from business, only one factor such as promising demand of the products/services have been found to have significant effect on profit in street business. It also might be because it is a very small scale business mostly doing for livelihood. Apart from several other ways of earning money for livelihood, basically as per the concept of business as well, entrepreneurs obviously start the kind of business which has a promising demand in the market. Therefore it is likely to have effect on profit from the business as well.

\section{Conclusions}

This study has found that level of education has moderate positive relationship with profit from the business (i.e. considered as an indicator of entrepreneurial success). Likewise, number of workers, size of initial investment on business and some motivational factors like family business and promising demand of the products/services are the major determinants on street entrepreneurial success. Among socio-economic factors, number of workers is the most important determinant followed by the size of initial investment in the business and among many motivational factors, promising demand of the products/services is the only one determinant of street entrepreneurial success.

\section{References}

Cooper, A.C. (1985). The Role of Incubator Organizations in Funding of Growth Oriented Firms. Journal of Business Venturing, 1(1).

Indarti, N. and Langenberg, M. Factors Affecting Business Success Among SMEs: Empirical Evidences from Indonesia. (Retrieved July 28, 2008, from www.utwente.nl/nikos/archief/research/conferences/esu/ papers/indartilangenberg.pdf)

Minniti, M. and Bygrave, WD (2003). National Entrepreneurship Assessment United States of America. Executive Report.

Panda, T.K. (n.d). Entrepreneurial Success key Indicator Analysis in Indian Context. (Retrieved July 29, 2008, from http://dspace.iimk.ac.in/bitstream/2259/199/1/entrepreneurial+success.pdf)

Raman, R. (2004). Motivating Factor of Educated Self Employed in Kerala: A Case Study of Mulanthuruthy Block Ernakulum. Discussion Paper No. 90. Kerala Research Programme on Local Development Center for Development Studies

Rose, R.C., Kumar, N. and Yen, L.L. (2006). The Dynamics of Entrepreneurs' Success Factors in Influencing Venture Growth. The Journal of Asia Entrepreneurship and Sustainability.2(2).

Swunney, J and Runyan, R. (2007). Native American Entrepreneur and Strategic Choice. The Journal of Development Entrepreneurship 2(3).

Thapa, A. (2007). Micro-enterprises and Household Income. The Journal of Nepalese Business Studies, 4(1):110118. Vol. 5, No. 1, pp 110-118. 